\title{
The Role of Human Capital Development in a Diversified Economy
}

\author{
OBO, EKPENYONG BASSEY (Ph.D) \\ IHEANACHO, MARYJOAN UGBOAKU (Ph.D) \\ LEBO, MONICA PETER \\ Department of Business Management \\ University of Calabar \\ Calabar
}

\begin{abstract}
This paper examines the importance of the human capital development in diversifying Nigerian economy, especially, given the fact that it is oil base economy. It argues that to achieve a successful diversification more time and other resources are required into developing human capital which will exert great impact on the direction of the nation economy. For this, the need for adequate investment in education and training, health and safety, infrastructural facilities and a hostile free work environment are necessary for these human elements to strive in different sectors of the economy. This paper review the effect human capitals have on the economy of Nigeria. It also proposes a framework for new direction. Finally, the paper went further to explain that, in doing so, the accumulated wealth of knowledge, skills, and competencies acquired by the human element remains a great asset to creating several innovative ideas that will re-direct the Nigerian economy from mono-product (oil) to non-oil sectors for future economic development.
\end{abstract}

Keywords: Human capital development, diversification, economic development

\section{Introduction}

Nigerian economy was agro based economy, until the emergence of crude oil. This development was welcome with a high hope and aspiration by the Nigerian people whose thinking was that the better days of the Nigerian nation and its people has arrived

Today, an emerging trend suggests that in the last years the economy has been growing without job creation and poverty reduction (Esu \& Udonwa, 2015). Our worriness in recent times, with the Nigeria's oil dependent economy is the fact that Nigerian government spent an estimated amount of over $\$ 8$ billion [US dollars] annually on servicing the industry in operations such as fabrication, engineering procurement, construction (EPC), front and engineering design (FEED), conceptual designs and seismic studies (Ihua, Ajayi \& Eloji, 2009). Now this figure may be projected to hit over several billion of dollars. Regrettably, despite those large sums of money spent in servicing this industry, only a very little proportion of the accruable profit is spent in Nigeria. (Ihua, Ajayi \& Eloji, 2009). This informed the reasons why all the infrastructural facilities that would have help in driving the economy of Nigeria to a greater development are in the state of decay today. Such as facilities in education \& health sectors, mines, power and energy, works $\&$ transports, Agro and water resources.

The good news now is that the country's dependence on oil can be reduce by investing in human capital development in all sectors of the economy. This aligned with Femi Adeshina as quoted in ASU (2013) as saying that Nigeria needed to envision and evolve a nation beyond oil or it could Perish. While Esu \& Udonwa (2015) noted that Nigeria must now diversify, or die, especially given the fact that for well over four decades we have run a mono-product economy. This observation agree with our problem that Nigeria has allowed the large sums of money from oil sector to stiff - necked other sectors and left them volatile in the economy. Therefore, a diversification effort that is people oriented, commitment - driven focused becomes indispensable to turn-around the economy of Nigeria for greater future.

\section{Definition of human capital}

The term "human capital has been defined as a collective capabilities, experience, skills, leadership, intelligence, commitment and general know - how of individual employees to solve problems (Liu, 2009; Gohen \& Kachemakis, 2007; Carson et al, 2004; Meritum, 2000; Bontis et al., 2000; Brooking, 1999). 
Isaac et al (2009) stated that human capital represents the value added by employees when they utilize their knowledge and other personal assets to produce goods and services that create wealth for their organization. Thus, to constantly sustain competitiveness in the organization, human capital becomes an instrument used to increase productivity (Marimuthus, Arokisanmy \& Ismail, 2009). In the same vein, human capital can be seen as "the knowledge, skills, competencies and attributes embodied in individuals that facilitate the creation of personal, social and economic wellbeing; (Organization for Economic Co-operation and Development, 2001). In support of this definitions United Nations Economic commission for Africa (1990) defined human capital to mean the knowledge, skills, attitudes, physical and managerial effort required to manipulate capital, technology and land, among other things to produce goods and services for human consumption.

On the other hand, human capital formation refers to the process of acquiring and increasing the number of persons who have the skills, education and experience that are critical for the sustainable growth and development of a country. Arising from this, human capital has been recognized as a key component for a country's socio-economic and political transformation. This therefore, means that the quality and quantity of human capital is very significant to a nation, as it is one of the main drivers of the impressive performance of the economy of most developed and the newly industrializing countries.

\section{Human capital theory}

Human capital theory is a theory that evolved from the field of macroeconomics development theory. Becker, 1993, Schultz, 1993, \& Schumpeter, 1942, were among those that propounded this theory. Major focus of the theory indicates how education increases human productivity by improving human knowledge and skills. Sullivan \& Sheffrin (2003) explain that increase in human productivity depends on the amount of education, training and experience acquired. While modern economists seems to agreed that education and health care are the key to improving human capital and ultimately increasing the economic outputs of the nation (Becker, 1993).

On the other hand, to grow the human capital in a way that would lead to higher productivity and macroeconomic growth, more schooling or learning is required (Livingstone, 1997). Becker (1993) as cited in Dike (2014) explained that the general education creates general human capital, while technical and vocational education provides specific human capital. These therefore, suggest that human capital theory assumes that formal education is the key driver of the productive capacity of the people (Schults, 1975, Psacharoponlos \& Woodhallm, 1997). The provision for formal education is therefore a productive investment in human capital, which is superior, in terms of outcomes, to similar investment on physical capital. In view of this Amobi (2008) noted that capital and natural resources are passive factors of production, human beings are the active agents which accumulate capital, explore natural resources, build social, economic and political organization, and carry forward national development. While in the word of Habison (1993) human capital constitute the ultimate basis for the wealth of nations.

However, on the social and economic importance of human capital theory Becker (1993) further explain that the most valuable of all capital is investment in human being which by implication develops the individual capabilities in diverse ways to improve on productivity. This therefore, proves that the economic development of any nation depends on its level of investment in human capital development.

\section{Human capital policies and its problems in Nigeria:}

\section{What is a policy?}

A policy is set of guidelines or rules that determines a course of action. It is a deliberate statement of direction adopted by government or an organization for guidance on various matters. A good policy spells out precisely what action should be taken in line with the policies made.

Armstrong, (2012) defines the overall HR policies as of how the organization fulfills its social responsibility for its employees and set attitudes towards them. It is an expression of its values or beliefs about how people will be treated. Human capital policies also provide formal rules and guidelines that are put in place to hire, train, asses and reward member at the workplace. These policies are clearly written and defined to give confidence and a sense of direction to both the employee and employer. In addition, there are certain core values usually enshrined in the overall policy statement, and these were identified by Armstrong (2012) to include:

Equity: this involves treating employees fairly and justly by adopting an "even handed" approach, such as protecting individuals from any unfair decisions made by their managers, providing equal opportunities for employment, promotion and operating an equitable payment system. 
Consideration: Is a process of taking account of circumstance when making decisions that affect the prospects, security or self - respect of employees.

Organizational learning: This has to do with one belief in the need to promote the learning and development of all the members of the organization by providing the processes and support required.

Performance through people: It has to do with the importance attached to developing a performance culture and continuous improvement, the significance of performance management as a means of defining and agreeing mutual expectations, the provision of fair feedback to employee on how well they are performing.

Quality of working life: Is a conscious effort aiming at improving the quality of working life. This involves increasing the sense of satisfaction; people obtain from their work by way of reducing monotony, increasing variety, autonomy and responsibility, avoiding placing people under too much stress and providing for an acceptable balance between work and life outside work.

Working conditions: Is the ability to provide healthy, safe and practicable pleasant working conditions.

Specifically, two key HR policies are paramount to human capital development and they are education and health. Education is concerned with the cultivation of the whole person including intellectual, character and psychomotor development. It is the human resource of any nation, rather than its physical capital and material resources, which ultimately determine the character and pace of its economic and social development (Aluko \& Aluko 2012.). However, the central position education occupies makes it the turning point for every form of development. The fact remains that when people are properly educated they are better informed with skills, abilities, knowledge, capabilities that communicates usage of their creative talent for transformation of resources to economic growth and development. Also, the popular view that Health is wealth is not an understatement.

The health sector in every country, is critical to social and economic development with ample evidence linking productivity to quality of health care (Ifejuka, 2017). Hence, people who are free from diseases, sicknesses or any form of deformity have the capacity and mental alertness of putting more hours to work. The soundness of health is a license of exerting more energy to being productive. Good health increases the productivity of nation's labour force, while productivity would be low in a country where a large proportion of human population lacks good health (Ifejika, 2017). Health and safety policies are concerned about the protection of the organization's employee from hazards at work and indicate how this protection will be provided (Armstrong, 2012).

\section{Problems of human capital policies in Nigeria}

Nigeria is immensely endowed both in natural and human resources and the pool of resources from one end to the other is unquantifiable. Education and health sectors are underfunded by government at federal, states and local government levels, the little funding appropriated for these sectors were mismanaged, thereby leading to death of human capital.

In the education sector - Public schools lack adequate funding to provide quality education to pupils and students; the private schools in the society are beyond the reach of the common people (Kakwagh \& Ikwuba 2010). While tertiary institutions are turning out half-baked graduates that are less useful in the labour market.

In the health sector - Capital flight continues to dominate the health sector in the country. While the political class and other rich Nigerians feel comfortable for seeking medical attention abroad, even as most qualified doctors in the country keep moving overseas at the slightest opportunity (Khaliq, 2019), of course these are the end product of lack of investment in human capital development; there is absolute neglect in infrastructure and number of institutions that drives the economy, for example federal roads/states roads all over the country are dead traps to passengers and motorist as they are in a very bad shape.

Energy supply - Every sector of any economy require good electricity supply to operate effectively. In Nigeria, the case is different as electricity supply is in a very poor state such that the business environment is no longer friendly; hence many business organizations especially manufacturing industries are closing down, thereby creating room for unemployment and crime. As a result of this, most of the industries are relocating to neighbouring countries with alluring business environment. This therefore, call for urgent and significant investment in a electricity generation and transmission, establishment of substations in every state in Nigeria, provision of the pre-paid and industrial meters, and other equipment and services that will make electricity available in private residences, business centers and industries for economic activities to thrive. 
Inconsistency in policy and poor policy implementation - various policies were put in place by the successive government to develop the human capital. However, lack of continuity and inconsistency in the implementation of these policies has created serious problem for the Nation. For example in the education sector, there exist catalogue of policies which were not allowed to bear fruits. They include U.P.E (Universal Primary Education) 6.3.3.4 system, UBE (Universal basic education) Almajiri Schools for the nomadic. The same applies to the health sector - where most of the policies were implemented partially while some, not at all. This has led to incessant unrest in these sectors. Consequently, this has a long term effect on human capital development in Nigeria.

Inconsistency in budgetary - allocation to education and health: The characteristics pattern of government's allocation to education and health in Nigeria as a percentage of the total budget revealed inconsistency. That is health and education expenditure were not considered as policy targets in the overall budgeting, or else, they would have maintained an increasing proportion of the yearly budget (Aigbokan, Imahen and Ailemen, 2007).

Non development of national capability: The educations offered in the universities are not properly geared to the area of needs of the country's economic development. Nigeria still, imports experts on engineering and other skilled workers. In the words of the director, Emerald Energy Institute, University of port Harcourt Prof. Wumi ILerare: "we don't have adequate skills that enable us to close the skill gap in the energy industry, and by extension, Nigeria economy. We do not have many engineers who can go into deep part of the ocean to weld and do various engineering works and design.

Corruption: One major challenge in education sector to the development of the system in Nigeria is corruption. It caught across all those in the position of authority in the educational sector. Torulagha in Ifejika (2017) outlined the corrupt practices done to education to include. The tiers of government who usually cut the funds meant for academic enhancement, capacity building, infrastructural development, modernization and rehabilitation of educational institution. Also, bureaucrats in various educational ministries and school officials responsible for administering the schools at various levels are also involved in this colossal looting. This attitude is a big minus in developing human capital.

Bad leaderships: leadership sets the tune of governance all over organization, even in the world today. Hence, poor leadership or leadership without a purpose is a setback to achieving the goals of economic development. Leadership is a process of getting things done through people (North house, 2007) it means responsibility" having passion for the purpose and mission of the organization or society. Nigeria lacks leadership with political will and commitment to implement effective policies that will transform the economy and tackle the socio-political problems facing the nation (Dike, 2014). Reporting on prioritizing human capital development in Nigeria's economy, Khaliq (2019) anchored on the words of Bill gate on this issue "Nigeria has unmatched economic potential, but what becomes of that potential depends on the choices Nigerian leaders make. Nigeria leader are political in nature, they snatched the mandate of the citizenry for selfish interest, and the result of their action affects the country's economic growth.

Insecurity: is of the nagging problem confronting virtually every aspect of activities in Nigeria. The Islamist group Boko Haram, Kidnappers, herdsmen and other crime groups go to schools, villages and market places to kill and destroy people's lives and looting properties, people flee from their dwelling places to neigbouring cities or town in search of safety. The environment is very unhealthy for economic activities to take place. No government can prosper in such a chaotic environment.

\section{Relationship between human capital and diversified economy}

Diversification is an important strategy that any business organization, institutions or a country could adopt for survival and development without being dependent on one or two aspects of business operation for economic development and expansion. Diversification refers to a strategy involving change in people's idea integrated to achieve distinct and alternative technologies for performance. Also Marangu, Oyayi and Gongera (2014) defines diversification as a means through which a wide range of products, services interest or competences are developed or acquired in order to achieve success and risk reduction in corporate operation.

Basically human capital relates to diversification as a change agent, that showcases areas of competence in people. This could be directed to their competitive advantage through specialization that catches the needs of the society. For instance, Nigeria using the intellectual capacity of her people (especially educated elites) through brain storming and/ or engineering of ideas, knowledge and skills to design or create a blue print to re-direct the mono-economy based to non-oil sectors, such as agriculture, tourism, solid mineral, arts, culture and so on. These can yield revenue that could be used to re-vitalize other sectors into meaningful economic development. 
Another relationship between human capital and diversified economy lies in the fact that diversification enhances people's choices. This reflects to the stream of economic activities that would be available for individuals to work or earn a living (such as commerce, production, agro and marketing industries) which act as agent of economic development. Furthermore, we tend to view the relationship of diversification and human capital in line with knowledge, skills, ability and competences as they have a high level of link with creativity, innovation and technological know-how among individuals which aids the needs of the society.

When human capital is properly accessed, the benefit of diversified economy leads to economic activities of transformation that will re-engineer the economy. It helps to improve people's welfare and increase the level of standard of living as well as revenue generation for the government.

We further observed that there is a strong relationship between human capital and diversification through provision of employment. One of the attribute to human capital is individual employability, because the individual is expected to have received education and training. In order words, he has acquired various skills, such as (technological, innovative and entrepreneurship skills). With these skills, the individual can easily be employed. Therefore in a diversified economy, creation of new ideas and different activities, related and unrelated products, gives room for more employment in different fields of human endeavour. However, Nigeria is one country, in the world that is richly blessed with diverse resources and spatial differences in resource endowment that is seen as a strong basis for economic diversification. Thus, the way lies in focusing on developing human capital and improving other infrastructural facilities that will serve as a driving force in the diversification process in both public and private sectors of the Nigerian economy.

\section{Human capital and economic development}

Today industries, marketing and service organizations are driven by complex technology, schooling, on-the-job training and other forms of training. Thus, high investment in human capital often lead to a workforce that possesses the skill base that is necessary for economic development. Indeed, there has been evidence that the $19^{\text {th }}$ and $20^{\text {th }}$ century growth in per capita incomes of a number of countries was driven in part by an expansion is scientific and technical knowledge (Duke, 2011). In addition the rapid recovery and reconstruction of the economics of the world powers that were defeated during the Second World War was a result of the productivity of labour and other improvements linked to human capital development (Becker, 1993; Marshall, 1998).

When applied human capital model, Robert (1991) observed that education significantly impacted on the development of human capital, and human capital in turn influences the economic development of nations. Duke (2011) explain that the dramatic growth of Asian countries economy, notably Taiwan, Singapore, Hong Kong, Korea, Malaysia, Indonesia and Japan evidenced this fact. He further explain that in spite of the odds stacked against these nations in terms of their total lack of natural resources (non - human), population explosion, dependence on Western and other nations for energy and the discrimination against their products in western markets, these countries have grown internally and are currently dominating the world using their well - educated, trained, conscientious workforce.

\section{Framework for new direction of Nigerian economy}

The framework for diversifying economy through human capital are identified in two streams

a. Human capital management: the strategies which drive economic development

i. Adequate funding to education and other forms of training: government should increase its budgetary allocation to education and other forms of training. Also enforce formally organized education at the elementary, secondary and higher levels; on the job training, including old-type apprenticeships organization by firms

ii. Government should evolve a mechanism that will facilitate public and private partnership that will enhance development in education and other forms of training.

iii. Mobility;' both public and private institutions should encourage migration of individuals and families to adjust to changing job opportunities, as well as exposure to international best standards.

iv. Health: adequate investment in health facilities and services should be seen as a major priority, broadly conceived to include all expenditure that the life expectancy, strength and stamina and the vigor and vitality of the people.

v. Safety: investment in safety both on the roads, water and air and in the industries and companies infrastructural equipments and practices should be encourage

b. Human capital management: the practices which drive economy development 
i. Global view with local adaptation of practices: this implies that our local companies and industries should seek for knowledge and technological transfer from developed economy that will help in improving their current practices.

ii. Promoting and enforcing ethical practice: the public and private institutions must ensure that all their activities are conform with various ethical practices, as well as in our private life.

iii. Creating the right policies and strategies with levity, while standard and bench marking should be encourage especially in areas such as education, health, safety and environment

iv. Performance management system and people development: the right people should be assigned to do the right work, compensation and reward systems should be transparent and accountable for, and also link to performance

v. Corporate social responsibility and responsibility to citizens: government and private businesses should exercise their responsibility in the area of society and communities' development, as this will go a long way in creating enabling environment for business and economic activities to thrive.

\section{Conclusion}

Every country in the world today operates in a fast changing environment where resources are limited and competition is fierce. To achieve sustainable development and growth requires a complex matrix of interrelated factors and at the center of all these is human capital which constitute critical success factor and catalysts for accelerating economic development.

However, we can only achieve this, through the quality of training we give to our people, therefore, we must attract, engage, retain, motivate and develop our best people to achieve any competitive advantage. Above all, patient, complex management approach and a strong leadership are inevitable.

\section{References}

Amobi, D. S. C. (2008). The human capital and millennium development goals in Nigeria: The possibilities and impossibilities. Journal of policy and development studies. 2(1). $17-23$

Armstrong, M. (2012). Human Resource Management. Practice. London: Kogan Page limited.

Asu, F. (2013). Diversifying Nigeria's oil dominated economic portfolio. August 29 http:// businessdayonline.com

Becker, G. S. (1993). Human capital: A theoretical and empirical analysis, with special reference to education. $\left(3^{\text {rd }}\right.$ ed). Chicago, IL: University of Chicago press.

Bontia, N. (1998). Intellectual capital: An exploratory study that develops measure models: Management Decisions, 36(2): $6-76$

Bontis, N. Wilham Chua, C. K. \& Rucharadson, S. (2000). Intellectual capital and business performance in Malaysian Industries. Journal of Intellectual capital. 1 (1), 85 - 100.

Brooking, A. (1999). Corporate memory: strategies for knowledge management: London: international Thomson business press

Carson, E. Ranzijn, Winefield, A. \& Marsdon, H. (2004). Intellectual capital: mapping employee and work group attributes. Journal of Intellectual capital, 5(3), $443-463$

Cohen, S. \& Kaimenakis, N. (2007). Intellectual capital and corporate performance in knowledge - intensive SMEs. Learning organization, 14 (3), $241-267$

Dike, V. E. (2014). Leadership and the Nigerian economy. Dd: 10.1177/2158244014523792. SAGE

Duke, J. (2011). Importance of identifying and analyzing business developments needs for economic survival and sustainable development through human capital Paper presented at $2^{\text {nd }}$ State Annual Conference of the Chartered Institute of Personnel Management of Nigeria, 2011 Calabar.

Esu, G. E. \& Udonwa, U. (2015). Economic diversification and economic growth: evidence from Nigeria. Journal of Economics and Sustainable Development, 6(6) 56 - 68.

Harbison, E. H. (1973). "Objective Machinery and Methodology of manpower planning" in T.M. Yesufu. Manpower problem and economic development in Nigeria, Lagos: OUP.

Ifejika, S. I. (2017). The challenges of human capital development in Nigeria: (theoretical insight: Silpakorn. University Journal of social sciences, Humanities and Arts 17(2), 41 - 74. 
Ihua, U. B. \& Ajayi, C., \& Eloji, K. N. (2009). Nigerian content policy in the oil and gas industry: implications for small to medium sized oil - service companies: A Paper presented at International Conference on Repositioning African Business and Development for $21^{\text {st }}$ century, 2009 IAABD.

Isaac, R. G. Herremans, I. M. \& Kline, T. J. (2010). Intellectual capital management enablers: A structural equation modeling analysis. Journal of business ethics, 93 (3) 373 - 391.

Jonathan, G. E. (2013). Nigeria must urgently diversify the economy from crude oil, July 12, https:// www.premiumtimeng.com/news

Liu, C. (2009). Study on the effect of intellectual capital on firm performance. Paper presented at the international conference on management of e-commerce and e-government, ICMECG 2009 Narchang.

Livingstone, D. W. (1997). The limits of human capital theory: Expanding knowledge, informal learning and underemployment. http://www.irpp.org/pe/archieve/ju/07/living St. pdf.

Marangu, W., Oyagi \& Gongera, E. G. (2014). An analysis of concentric diversification strategy on organizational competitiveness: case of sugar firms in Kenya. European Journal of Business and Management 6(19); 175 180.

Marimuthu, M., Arokiasamy, L. \& Ismail, M. (2009). Human capital development and its impact on firm performance: evidence from development economics. The Journal of International social Research, 2 (8), Summar 261 272.

Marshall, G. (1998). A dictionary of sociology: human capital theory: http://www.emcyclopedia.com/doc/1088humancapital theory.html.

Northhouse, G. (2007). Refocusing science and technology education toward national development. Knowledge review: A multidisciplinary Journal of NAFAK, 15 (6), 53 - 55

Organization for economic co-operation and development (OECD, 2001). The well - being of Nation: The Role of Human social capital. Paris: OECD.

Pscharopoulos, G. \& Woodhall, M. (1997). Education for development: An analysis of investment choice. New York: oxford University press.

Rober, B. (1991). Economic growth in a cross section of countries. Quarterly Journal of Economics, 106 (2), 407 - 414

Schultz, T. (1975). The value of the ability to deal with disequilibria. Journal of Economics Literature, 13(3), $827-$ 846.

Schultz, T. W. (1993). Origins of increasing returns, oxford, Uk: Blackwell

Schumpeter, J. A. (1942). Capitalism, Socialism and democracy. New York: Harper (Reprinted by Harper Colphon, 1995).

Sullivan, A. \& Sheffrin, S. M. (2003). Economics: principles in action. Upper saddle river, New Jersey: Pearson prentice Hall.

Zaka, Ald, K. (2019). Leadership. https:// allafrica.com.stories 